\title{
Editorial: \\ Teaching intellectual property rights as part of the information literacy syllabus.
}

\begin{tabular}{|c|c|}
\hline & Abstract \\
\hline Purpose of this paper & $\begin{array}{l}\text { To argue that, in the knowledge economy, those who } \\
\text { are expert in understanding intellectual property } \\
\text { issues, such as librarians and information } \\
\text { professionals, have a special responsibility for creating } \\
\text { policy, encouraging understanding and resolving legal } \\
\text { disputes and conflicts unique to this aspect of the } \\
\text { information society. One way of achieving this is } \\
\text { through the educational impact of systematic } \\
\text { information literacy programmes which include } \\
\text { intellectual property issues as part of the syllabus. }\end{array}$ \\
\hline Design/methodology/approach & An overview of current practice and current opinion. \\
\hline Findings & $\begin{array}{l}\text { That the current culture, in higher education } \\
\text { especially, towards intellectual property rights remains } \\
\text { both confused and confusing, above all for the } \\
\text { 'information illiterate' starting out on degree-level } \\
\text { programmes. Attitudes and policies need to be } \\
\text { clarified so that a coherent approach to a range of } \\
\text { different but related IP matters such as plagiarism, } \\
\text { self-archiving on research repositories and respect for } \\
\text { commercially owned copyright material is uniformly } \\
\text { developed. Debate must be differentiated from policy } \\
\text { which in turn must be implemented via the IL } \\
\text { syllabus. }\end{array}$ \\
\hline $\begin{array}{l}\text { Research limitations/ } \\
\text { Implications }\end{array}$ & $\begin{array}{l}\text { This is a statement of opinion that could be tested by } \\
\text { practical case study investigation. }\end{array}$ \\
\hline Practical implications & $\begin{array}{l}\text { Suggests that information literacy programmes be } \\
\text { promoted as a way of enhancing student } \\
\text { understanding of intellectual property issues. }\end{array}$ \\
\hline $\begin{array}{l}\text { What is original/value of the } \\
\text { paper? }\end{array}$ & $\begin{array}{l}\text { This paper brings together different IP issues which } \\
\text { are not normally considered together, such as } \\
\text { institutional research repositories, student plagiarism } \\
\text { and commercial IP entitlements. It points out ways of } \\
\text { unifying these in a single coherent philosophy of } \\
\text { information society rights and ownership. This } \\
\text { philosophy should form one of the mainstays of the } \\
\text { information literacy syllabus. }\end{array}$ \\
\hline
\end{tabular}

Paper type: Viewpoint

Keywords: Universities; information services; literacy; intellectual property rights.

This is a peer-reviewed author accepted manuscript of the following research article:

Joint, N. (2006), "Teaching intellectual property rights as part of the information literacy

syllabus", Library Review, Vol. 55 No. 6, pp. 330-336.

https://doi.org/10.1108/00242530610674730 
To borrow a phrase from a great classic author, ${ }^{1}$ it is a truth universally acknowledged that the information literate individual requires an understanding of intellectual property (IP) issues ${ }^{2}$. And gradually, it is also becoming acknowledged that librarians, researchers, teachers and lecturers all share the responsibility for nurturing this ability. Admittedly, what the content of the Information Literacy (IL) syllabus should be, who should teach it and how they should teach it, are other matters, where controversy as much as collegiality predominates. But the connection between 'IP' awareness and ' $I L$ ' is a given.

Within the library world, practitioner librarians often take the approach that IL can be nurtured in two ways: proactively or reactively. Proactive IL work consists of training students or inexperienced information users to be information literate before they encounter information literacy problems. Reactive IL work manifests itself in a variety of ways, but most commonly the activity of 'reference librarianship' can be viewed as synonymous with 'reactive IL work'. Answering a reference enquiry is merely a reaction to a request for IL training after, rather than before the user has encountered an information problem and failed to find an answer to it. The request 'Please give me information about such-and-such' should thus be met with the reply, 'Here is that information, but more important, here's how to find it yourself in future.' The crucial skill is to offer, not just an answer, but also the extra support for the reader: at that point reference work becomes reactive information literacy training.

Advocates of 'reactive IL' are conservative voices occupying an important sceptical position a little outside the mainstream of the information literacy movement. They have some cogent arguments on their side, which ring a loud bell with many practitioners. Here is my own rendition of this argument, which I have heard in various forms over the years:

"IL classes are essentially unteachable because you can't teach the subject in the abstract: you need users to have a real information problem before you can engage student interest. So it's best to react to student dissatisfaction when they have genuine personal experience of information literacy problems which they then bring to the library. Otherwise it's all pretend, an exercise in pushing the uninteresting into the faces of the uninterested."

Anyone who has failed to create a dynamic sense of interest in students in a library skills class (and many of us fall into this category!) will find this argument quite compelling.

However, before we yield to such defeatism, there is one question that must be asked. If respect for intellectual property rights is part of the IL syllabus, do we really want to wait until our own educational institution has a major rights violation on its hands before we start to 'react' to the problem of low levels of information literacy in our library users? The reactive approach could prove an expensive and time-consuming one in such a scenario!

Therefore the mainstream voice of the IL movement would say quite justifiably that waiting to react to IP breaches committed by the information illiterate is a bad idea. But to prove this case objectively, one must examine the facts of intellectual property violations in the real world of digital library practice. Can we wait for things

This is a peer-reviewed author accepted manuscript of the following research article: Joint, N. (2006), "Teaching intellectual property rights as part of the information literacy syllabus", Library Review, Vol. 55 No. 6, pp. 330-336.

https://doi.org/10.1108/00242530610674730 
to go wrong, or is it best to take avoiding action (in the shape of a coherent comprehensive IL programme) well beforehand?

Waiting for problems to arise is fine if the problems are not that disastrous... but this is where another dilemma appears. There are those in education and research who appear to look on certain IP matters in terms of bureaucratic constraints which should be challenged rather than obeyed. In particular, much of the early rhetoric surrounding the creation of institutional research repositories has sounded as if the repossession by research institutions of the IP (academic papers) which they have given away to commercial publishers is almost a benign act of civil disobedience:

"And everyone should have the right to 'mirror' articles; that is, to republish them verbatim with proper attribution.

"These rules should apply to past as well as future articles, when they are distributed in electronic form. But there is no crucial need to change the present copyright system as it applies to paper publication of journals because the problem is not in that domain..."

"...When copyright impedes the progress of science, science must push copyright out of the way." 3

Ironically, the reality of how institutional research repositories have in fact been created could not be further from this adventurous approach to IP matters. The existence of services such as the SHERPA/RoMEO 4 permissions web site is evidence of the punctilious approach to copyright adopted by practitioners in the creation of such digital research libraries - and unsurprisingly, many of these practitioners have trained as librarians.

So the reactive approach to the copyright dimension of IL would be fine if IP constraints were rightly viewed as unimportant in research and teaching practice. But they are not. Yet in spite of this, a casual approach to the importance of copyright as part of information management and IL awareness might be encouraged by the tone of comments such as the previous quotation, and again by the following, which I would suggest can easily be misconstrued by the naïve reader as dismissing copyright law as 'officious fluff':

"Now, before everyone starts squawking about all sorts of legalistic and pedantic niceties, sit and think about it for a few moments, and try to sort out what really has substance in all this, and what is just officious fluff."

This statement from Prof. Stevan Harnad is in fact proposing a liberal but highly rational interpretation of the specific legalities concerning one narrow issue: IP in institutional research repositories and how universities can legally submit research submissions (published as the intellectual property of commercial publishers) to the UK Research Assessment Exercise panels. His expansively argued advice on this topic is fully expounded in a public email correspondence starting on the Jiscmail LIS-E-JOURNALS list ${ }^{5}$ (which is then developed elsewhere in a discussion with copyright guru Charles Oppenheim ${ }^{6}$ ).

This is a peer-reviewed author accepted manuscript of the following research article: Joint, N. (2006), "Teaching intellectual property rights as part of the information literacy syllabus", Library Review, Vol. 55 No. 6, pp. 330-336.

https://doi.org/10.1108/00242530610674730 
What is worth highlighting here is the emotional tenor of these robust and entertainingly expressed opinions. This high octane approach to IP matters is confusing to the information illiterate who in consequence may be encouraged more generally to disregard IP issues as they pursue their educational activities. These comments, made as part of the arcane debate about institutional repository copyright, may merge in the minds of the ignorant with other casual statements about a range of IP issues made by those who perhaps possess a more vague awareness of IP constraints. A texture of non-compliance can thus build up. And again, if the consequences of so doing were negligible then a reactive response to IP anomalies would generally be fine - let the breaches happen and let the culprit explore the ethics and legalities of the situation as a sort of spontaneous case study. But this is not the case.

Thus, the central tenet of this short paper is that such well-intentioned advocacy of IP 'liberalism' can be misunderstood as ethically permitted disobedience, because of the absence of obligatory information literacy training for all as a means of putting this IP debate into context. In that sense, 'IP liberalism' can be harmful. Therefore, our discussion and teaching of IP matters should be temperate, and not controversialist in tone (let alone in content). Intellectual property and other equivalent rights exist in law for a reason, and although one may chafe against such constraints, they are a reality. The information literacy movement exists, among other things, to consecrate the realities of IP law in educational practice. Academic voices which albeit unintentionally undermine this respect for intellectual property in fact are arguing against the core values of the information literacy movement.

From a theoretical point of view, there may indeed be moral reasons why a law should be defied. It is a perfectly rational ethical argument that where intellectual property law creates a false market for a commodity, for example, by restricting supply and raising price in the face of reasonable demand, then the law is an ass. It is (arguably) a brave and noble thing to break the law in such cases in order to promote the freedom of information exchange and academic discourse.

However, returning to the humble world of library practice where we avoid courageous actions at all costs, practitioners must ask, what are the real consequences of being cavalier with IP? For example, what happens in reality when you unintentionally encourage a casual attitude amongst naïve students to the downloading of publisher pdf files of commercial e-journal articles?

Firstly, there are ways in which breaches of intellectual property rights can be easily detected. Commercial publishers' servers can be set up in such a way that wholesale downloading of journal files can be spotted. If more than a certain number of files are taken from a given journal title within a short space of time, then the rights holders will justifiably think that something illicit is probably going on. The ip address from which the downloading took place can be denied access to all the electronic journals which that rights holder (the e-journal supplier) provides.

Since most big educational institutions or companies use a single top level proxy cache through which all their campus traffic is routed, denial of access via that cache's ip address denies access to everyone in that institution. And if the commercial publisher whose rights have been violated is a big portfolio supplier, the result is a loss of access to a mass of titles, not just for the perpetrator but for

This is a peer-reviewed author accepted manuscript of the following research article: Joint, N. (2006), "Teaching intellectual property rights as part of the information literacy syllabus", Library Review, Vol. 55 No. 6, pp. 330-336.

https://doi.org/10.1108/00242530610674730 
everyone in a large HEI or corporation until the origin of the breach is dealt with. Imagine a large British University being denied access (say) to all of Elsevier Science Direct for an indefinite amount of time until the individual perpetrator of a rights violation is traced and punished, with assurances (if not damages!) given to the rights holders.

And in case the mention of damages seems alarmist, it is salutary to note that awards of damages to aggrieved rights holders are not unknown, certainly not in the British university system. Most experienced LIS practitioners are aware of them, at least anecdotally, and have some idea of how damages might be calculated. If a publisher's pdf is loaded without permission into a VLE class area and accessed by 100 hundred students each year over three years, how unreasonable would it be for a rights holder to calculate a bill for damages based on the value of the one-off purchase of the pdf (some $£ 25.00$ via a document delivery service), multiplied by the number of students per annum, multiplied by the number of years of access? Working out such sums is a valuable exercise which indeed helps us to separate "what really has substance in all this, and what is just officious fluff."

No HE professional should be in the position of parents whose children inadvertently wander into the perilous waters of illegal file-sharing via their home pc. Undoubtedly the parents of children who have had to pay significant fines on behalf of their offspring's illegal file-sharing will be regretting the failure of their kids' schools to promote an information literate understanding of IP law ${ }^{7}$. But HEIs are supposedly better at promoting information literacy and their employees are supposed to know about such things!

What LIS professionals in particular, and educators in general, must not lose sight of here is the plight of the individual student with their possibly minimal individual level of information literacy. If IL programmes do not make it clear to students what a rights breach is, then they will not be protected against the consequences of their ignorance in these matters. This is especially true when, for example, much of the rhetoric surrounding the creation of institutional research repositories from material destined for commercially published journal output sounds to the uninitiated as if it is official approval from the leaders of Higher Education for rights breaches. I do emphasise the word sounds like, because of course no-one in $\mathrm{HE}$ at any level is advocating deliberate breaching of IP law.

But it is very hard for a student, even a sophisticated research student, hearing that the wholesale upload of 'author final drafts' of journal articles onto an Institutional Repository is widely considered legal and may soon be mandated by the Research Councils UK, to distinguish that activity from wholesale downloading of publisher pdfs from a commercial e-journal site to their USB stick.

Indeed, for a research student from a developing country, it may seem that the institutional repository movement gives them the ethical green light to download entire e-journals in order to distribute the resultant store of publisher pdfs to scientists in their impoverished home institutions. Isn't this what the exhortation for science to 'push copyright aside' could mean to some? But no, there is a very important distinction between the two activities, and this distinction needs to be imparted carefully in systematic information literacy programmes that should be obligatory for all would-be graduates in Higher Education.

This is a peer-reviewed author accepted manuscript of the following research article: Joint, N. (2006), "Teaching intellectual property rights as part of the information literacy syllabus", Library Review, Vol. 55 No. 6, pp. 330-336.

https://doi.org/10.1108/00242530610674730 
This is particularly important in that IP issues overlap very significantly with another area of concern in education today, plagiarism issues. After all, plagiarism occurs when one person's intellectual property is passed off as another's, with or without the agreement of the original rights owner. All academic staff deplore plagiarism, and plagiarism amongst academic staff is a career-shortening infringement. Above all, plagiarism amongst students, apart from being ethically and legally unsound, deprives the plagiarising student of the benefits of true personal educational development.

Yet educators cannot deplore IP breaches in one sphere while appearing to incite them in another. It is undoubtedly unfortunate that high quality academic journals are expensive, and their price does to some degree curtail the wider circulation of research information. 'Research' is a public good that is largely funded by public money and that public good should be distributed as widely as possible. That does not make it legal to play fast and loose with publisher pdfs from commercial ejournal sites, and it is best to avoid rhetorical statements which are liable to misinterpretation in this respect.

It is also important therefore that institutions commit themselves to legally wellfounded disciplinary procedures which ensure IP rights compliance from students and staff. Despite the cloaking effect of routing traffic via a single ip address, it is possible to trace illegal activity to any individual subsidiary ip address of a machine via which transgressors have gained authenticated access to the secure network. What should then happen once individual culprits are identified?

Before the more old-fashioned among us start dreaming up some of the more exotic punishments on offer for those who have committed a breach, it is advisable to consider the experience of North American Universities which have tried to enforce regulations against students guilty of IP breaches. In instances where the IP breach concerns plagiarism, then legally the punishment of exclusion from a course can only take place if the student has been demonstrably educated about the facts and regulations surrounding plagiarism. Reactive IL education is irrelevant: anticipation is everything.

When a University fails to educate students in this proactive way, they cannot then enforce compliance because the outcomes of official student grievance procedures have shown that ignorance or misunderstanding of the rules concerning plagiarism can be deemed an excuse. This means that if a student was failed or expelled because of plagiarism, a University might have to re-admit the student and even pay them damages for having punished them for a transgression they knew little or nothing about. Of course, the highly litigious North American context differs from other educational environments, but there is much to learn from it: British student plagiarists have been known to follow similar legal paths. ${ }^{8}$

It is possible therefore that disciplinary action against students who illegally download publisher pdfs from journal sites may be difficult when academics in universities are making statements about copyright that seem to imply a need to push copyright constraints to the limit. What works as a defence against plagiarism might work as a defence against copyright infringement committed with journal articles or even with digital learning objects.

This is a peer-reviewed author accepted manuscript of the following research article: Joint, N. (2006), "Teaching intellectual property rights as part of the information literacy syllabus", Library Review, Vol. 55 No. 6, pp. 330-336.

https://doi.org/10.1108/00242530610674730 
How then should a University insure itself against such breaches? A clear syllabus for each class or course with statements about IP violations is vital. But the best form of education in this area is a comprehensive, proactive information literacy programme, one in which librarians - with their measured, well-informed and painstaking approach to all such IP matters - play a crucial part.

And finally, here is a more wide-ranging historical argument for the importance of IP issues and information literacy in contemporary information society. As a rule of thumb (and I apologise for any oversimplification in this), at different stages of economic history different resources are seen as the main source of the wealth of that society. In the agrarian world of feudal economics, land was the root of wealth and wars over land rights predominated. In post-medieval industrial society, the ownership of industrial capital was the key to wealth creation. Social conflict then centred on ownership of the means of production of capital-based wealth, and class tension between capitalist and workers proliferated.

Many of these conflicts are behind us now. However, in the knowledge economy, the prime area of conflict will inevitably be over the production and ownership of knowledge, that is, over the possession of intellectual capital. So it is unlikely that the prime area of regulation for such conflict - legislation and litigation concerning intellectual property rights - can be dismissed merely as bureaucratic meddling. In its own way, this is as misleading as saying that the Peasants' Revolt was a minor mishap in the Middle Ages and the 1917 Revolution was a grumble about workers' rights that just got a bit out of hand. What makes people rich or poor in a particular type of economy really matters.

Now, we have yet to experience our first global war over a disputed patent application. But in the knowledge economy those who are expert in intellectual property have a special place of excellence with a responsibility for anticipating legal disputes and resolving the conflicts special to an information society. Librarians and information professionals are such experts, and it is important that we bring our expertise to bear on these problems, not least through the educational impact of information literacy programmes. But to do so, we must first win the argument for taking intellectual property issues seriously as part of systematic information literacy training: this paper is an attempt to provide material to help LIS professionals win that argument.

Nicholas Joint

Editor

'Library Review'

This is a peer-reviewed author accepted manuscript of the following research article: Joint, N. (2006), "Teaching intellectual property rights as part of the information literacy syllabus", Library Review, Vol. 55 No. 6, pp. 330-336.

https://doi.org/10.1108/00242530610674730 


\section{Notes and References}

1. Austen, Jane (1813). 'Pride and Prejudice' p. 1. http://www.pemberley.com/janeinfo/ppv1n01.html

2. To avoid confusion, please note that in this paper the upper case acronym IP is used in place of the phrase 'intellectual property', whereas the lower case version of the same letters is used as an acronym for the phrase 'internet protocol' in 'ip address'.

3. Stallman, R. (2001) "Science must 'push copyright aside' ". Nature - web debates http://www.nature.com/nature/debates/e-access/Articles/stallman.html

4. SHERPA/RoMEO web site: http://www.sherpa.ac.uk/romeo.php

5. LIS-E-JOURNALS Archive: http://www.jiscmail.ac.uk/lists/LIS-E-JOURNALS.html

6. Harnad, S. (2006). "Re: Question for publishers - Research Assessment Exercise 2008" [Email] American-Scientist-Open-Access-Forum http://www.ecs.soton.ac.uk/ harnad/Hypermail/Amsci/5122.html

7. BBC News website (2006). "Legal fight hits 'music pirates' " http://news.bbc.co.uk/1/hi/entertainment/music/4438324.stm

8. In Canada, a student's grade appeal, was upheld because a lecturer's syllabus "lacked crucial information on plagiarism and cheating policies". See:

a) "Big Brother is on the side of students" Sunday Times, September 21, 1997.

The later 2004 UK case concerning Michael Gunn echoes the earlier North American case. A plagiarising student can threaten litigation on the basis of not being given information about the nature of plagiarism:

b) Baty, P. (2004) "Plagiarist student set to sue University" Times Higher Education Supplement No. 1642 p. 1.

c) BBC News website (2004) "'Plagiarist' to sue University" http://news.bbc.co.uk/2/hi/uk news/education/3753065.stm

....although according to the Wikipedia entry for the University of Kent, the Michael Gunn plagiarism case never made it to court in the UK:

d) http://en.wikipedia.org/wiki/University of Kent.

Other students have settled out of court or have had better luck. One student successfully litigated in 2004 against their North American University over the

This is a peer-reviewed author accepted manuscript of the following research article:

Joint, N. (2006), "Teaching intellectual property rights as part of the information literacy syllabus", Library Review, Vol. 55 No. 6, pp. 330-336.

https://doi.org/10.1108/00242530610674730 
unfair use of plagiarism software:

e) CNN/Grinberg, G. (2004) "Student wins battle against plagiarism-detection requirement" http://www.cnn.com/2004/LAW/01/21/ctv.plagiarism/

...while in the UK a Law student has successfully litigated against South Bank University for low marks unfairly awarded due to a number of issues, one of which was plagiarism:

f) Green, J. (1996) "Going to law to save your career; It's the latest in student protest: young people are suing their universities." The Independent, August $22^{\text {nd }}$, p. 23.

(N. B. all urls accessed March $31^{\text {st }} 2006$ )

This is a peer-reviewed author accepted manuscript of the following research article:

Joint, N. (2006), "Teaching intellectual property rights as part of the information literacy syllabus", Library Review, Vol. 55 No. 6, pp. 330-336.

https://doi.org/10.1108/00242530610674730 